\title{
DEVELOPMENT OF BONE ASH FROM EPPAWALA APATITE - SRI LANKA AS A RAW MATERIAL FOR BONE CHINA PRODUCTION
}

\author{
I.A. BALASOORIYA ${ }^{1 *}$, H.M.J.C. PITAWALA ${ }^{1}$ \\ Department of Science and Technology, Faculty of Applied Sciences, \\ Uva Wellassa University, Sri Lanka \\ *Corresponding author: e-mail: imesha2512@gmail.com
}

(Received 15 $5^{\text {th }}$ December 2020; accepted 04 ${ }^{\text {th }}$ March 2021)

\begin{abstract}
Bone china is popular high grade porcelain with excellent characteristic features including translucency, whiteness, and high strength. Among its different components, Bone ash is recognized as the major raw material that provides above properties. However, as Bone ash is sourced from animal bones, its usage has some limitations. Therefore, finding other alternative sources for bone ash is an urgent matter. In this work, a novel bone china recipe was developed using a synthesized Bone ash analogue. The synthesized Bone ash analogue was produced by heat treating Eppawala apatite with calcium hydroxide. The product was then calcined at $900{ }^{\circ} \mathrm{C}$ and characterized using Fourier Transform Infrared (FTIR), X-Ray Diffraction (XRD) and X-Ray Fluorescence (XRF) spectroscopy. The FTIR results indicated that both synthesized sample and commercial bone ash have the characteristic, $\mathrm{PO}_{4}{ }^{3-}$ and $\mathrm{OH}^{-}$functional groups. The $\mathrm{XRD}$ and XRF data respectively revealed that the synthesized sample has the hexagonal crystal structure and very close chemical composition inherently match with the commercial bone ash. Finally, the novel bone china recipes were prepared by adding synthesized product partially with commercial bone ash. Among the prepared samples, the best product was fabricated after the addition of 5\% bone ash analogue. However, high amount of bone ash analogue (50\%) was not viable to cast by slip casting method. Therefore, it could be mentioned that even though the synthesized bone ash analogue is structurally, chemically, physically similar to commercially available bone ash, it could not totally replace the commercial one. However, there is a possibility to add some amount of synthesized bone ash analogue keeping the required quality of the industrial standard.
\end{abstract}

Keywords: Bone ash, Bone china, Eppawala Apatite

\section{INTRODUCTION}

Bone china is considered as the king of the porcelain industry as it shows some excellent properties compared to the other porcelain products. This product is the strongest and the lightest with a milky white appearance. It also exhibits translucency and emits chime sound (Smith, 2013). Bone ash is the responsible raw material to generate all these excellent properties (Zakaria and Haron, 2013). However, the addition of Bone ash to Bone china recipe is problematic (Irvine, 1980). Bone ash is sourced from animal bones and it is subjected to compositional variation with the changes in the type of animal bone used in the manufacturing process (Nijhawan, 1975). Further, as the high iron content in animal bones causes significant issues (Braganca and Bergmann, 2008; Mostari et al., 2017). Therefore, cow bones with lower iron content are more preferable (Singer, 1963). The availability of such good quality animal bones is low. Additionally, Bone ash is imported from foreign countries at considerably higher costs. This could lead to price increments in Bone china products. Due to these reasons, the demand for Bone china could go down.

To overcome these issues, previous studies have considered using substitutes for Bone ash. However, in certain methods phosphoric acid was used and the products have exhibited discolorations ( Irvine, 1980; Hills et al., 1998). Due to these drawbacks, an attempt was taken to synthesize a substitute for commercially available Bone ash using a local natural resource; Eppawala Apatite (Subasinghe, 1991) which is comparable to ordinary Bone ash. 


\section{METHODOLOGY}

\section{Bone Ash Preparation}

Eppawala apatite crystals were washed to remove mud and slime and those were oven dried. The brownish iron coating was removed by successive cutting and the pieces were crushed using the jaw crusher. The crushed pieces were ball milled under $700 \mathrm{rpm}$ for 30 minutes to obtain a fine powder. Then, $40.0 \mathrm{~g}$ of the fine apatite powder was weighed. Next, $8.0 \mathrm{~g}$ of calcium hydroxide $\left[\mathrm{Ca}(\mathrm{OH})_{2}\right]$ was added and the mixture was ball milled under $756 \mathrm{rpm}$ for 35 minutes. Then the mixture was heat treated in a Protherm muffle furnace at $900{ }^{\circ} \mathrm{C}$ for 3 hours and the product was calcined for 1 hour by gradually increasing the temperature up to 900 ${ }^{\circ} \mathrm{C}$ to remove volatile impurities.

The synthesized product was characterized using different experimental methods. Fourier Transform-Infrared (FTIR) spectroscopy was used to identify the structural features i.e. functional groups present in the synthesized product. The results were compared with the commercially available bone ash. Here, the FTIR spectra were recorded with a Bruker Alpha Spectrometer, over the region of $400-$ $4000 \mathrm{~cm}^{-1}$, by using $\mathrm{KBr}$ pellet technique.

X-ray powder diffraction (XRD) was used to determine the crystallographic structures of the reference and the synthesized samples. Rigaku ultima iv, X-ray diffractometer was used and the diffraction peaks were obtained in Bragg angle (20) of 20 to $60^{\circ}$, at room temperature. The impurities present in the samples and respective crystallographic planes were also detected.

Goldscope SD X-ray fluorescence Spectrometer was used for the elemental composition analysis of the synthesized and reference samples. The undesirable elements in the synthesized product were detected and their presence was compared with the reference sample to meet the industrial quality.

Bone China Preparation

Clay mixture preparation
In this study, a standard Bone china product was prepared to be used as the reference to clarify whether the developed Bone china product meets the specific standard properties. The procedure was adapted from the standard industrial methodologies.

First, feldspar was sieved by no 4 mesh sieve and oven dried. Then, commercially available Bone ash, washed kaolin, canton ball clay and bentonite were also oven dried. Then, $500 \mathrm{~g}$ of commercially available Bone ash, $200 \mathrm{~g}$ Feldspar, $200 \mathrm{~g}$ washed kaolin, $50 \mathrm{~g}$ canton ball clay, $50 \mathrm{~g}$ bentonite were weighed. Next, nonplastic raw materials and 50\% water were fed into the pot mill and milled for 20 hours. Particle size analysis was done for the mixture. Then, the plastic raw materials and 50\% percent water were added and milled for additional 2 hours. The particle size analysis was again carried out.

Next, the clay mixture was oven dried for 8 hours, at $120{ }^{\circ} \mathrm{C}$. The oven dried mixture was then crushed and fed into a pot mill. Then, $2 \mathrm{~g}$ of "aqualic" was added to suspend the particles evenly. Then, $30 \%$ of water was added to get the essential fluidity and the mixture was then milled for 1 hour. The viscosity of the slip was measured by Brook field viscosity meter. The additional "aqualic" was added for viscosity adjustments. Prepared slip was used to cast standard Bone china items and to prepare color slabs.

The standard Bone china recipe was altered by adding synthesized Bone ash analogue to prepare "test Bone china" products. The used percentages are given in Table 1.

Table 1. The percentages of Bone ash used in the different Bone china recipes.

\begin{tabular}{ccl}
\hline $\begin{array}{c}\text { Commercially } \\
\text { available Bone } \\
\text { ash }(\%)\end{array}$ & $\begin{array}{c}\text { Synthesized } \\
\text { Bone ash } \\
(\%)\end{array}$ & $\begin{array}{l}\text { Product } \\
\text { code }\end{array}$ \\
\hline 45 & 5 & BC_1 \\
40 & 10 & BC_2 \\
30 & 20 & BC_3 \\
20 & 30 & BC_4 \\
10 & 40 & BC_5 \\
0 & 50 & BC_6 \\
\hline
\end{tabular}


The slip for the test ware was prepared by following the similar method used in standard recipe preparation.

\section{Bone china casting}

The prepared slips were poured in to plaster of paris molds and the items were cast by drain casting method. The cast items were kept at the room temperature $\left(26^{\circ} \mathrm{C}\right)$ and they were water sponged and the drain marks were removed. The items were then air-brushed and oven dried at $100{ }^{\circ} \mathrm{C}$ for 1 hour. Then, the items were fired in a "GRHK" kiln for 10 hours at a temperature of $1235^{\circ} \mathrm{C}$, under oxidizing conditions.

The hard biscuits were fed in to Boroton machine i.e. a machine consists of small pebbles. When an item is inserted, the machine vibrates and the small pebbles hit the surface of the item to remove its undulations to make the surface smooth. Then, they were air-brushed to remove dust and other attached particles. After that, the items were heated to $100{ }^{\circ} \mathrm{C}$ and spray glazed. They were fired in GK III kiln at a temperature of $1135-1155{ }^{\circ} \mathrm{C}$, under oxidizing conditions to obtain both standard and test Bone china items.

\section{Laboratory Tests}

All the laboratory tests were carried out according to the industrial standers that they use in the factory.

\section{Particle size determination}

First, two samples from the ball milled clay mixtures were taken. Then $5-6 \mathrm{~g}$ from the samples was spread in cleaned and dried plates of the moisture meter. After 10 minutes, the moisture meter readings were obtained as the moisture contents of the clay mixtures. Next, the amount of clay mixtures required for the particle size determination was calculated according to the following formula;

$$
\begin{gathered}
\text { Required } \\
\text { amount of } \\
\text { clay mixture }
\end{gathered}=\left\{\frac{100}{100 \text {-moisture }}\right\} \times 30
$$

Then, the required amounts of clay mixtures were weighed into cleaned and dried beakers and $10 \mathrm{~g}$ of sodium pyrophosphate and $550 \mathrm{ml}$ of soft water were added. Next the mixtures were separately fed in to two measuring cylinders, and two hydrometers were inserted. The initial hydrometer readings was taken. After 20 minutes the second set of readings were taken. Then the particle sizes of the mixtures were calculated according to the following formula.

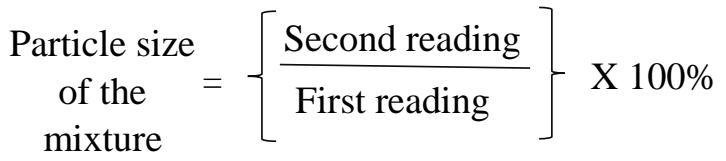

The milling process was continued until the particle sizes of the two mixtures reached the range of 78-82 $\mu \mathrm{m}$. When the particle size of the mixture reached the range of 78-82 $\mu \mathrm{m}$, essential quantities of dried kaolin and ball clay were added as the second addition, to the above mixtures separately. Then the ball mills were filled with 60-62\% water and milled for 2 hours to mix all the raw materials well and to further reduce the particle size down to the range of 80 $84 \mu \mathrm{m}$. Finally the clay mixtures were unloaded and they were oven dried for 8 hours to remove moisture.

\section{Casting rate determination}

The casting rates of the two slips were determined. Two cleaned and dried molds were placed on a flat ceramic plate. Then, the two slips were poured into the two molds separately. After 30 minutes the excess of the slips were poured out. Next the thickness of the pieces left on the ceramic plates were measured. Casting rate data were used in the drain casting process.

\section{Color slab preparation}

First, the slips were poured into color slab molds. The molds were detached after one hour. Then, the obtained color slabs were dried in the room temperature of $26{ }^{\circ} \mathrm{C}$. Next, they were oven dried at $80{ }^{\circ} \mathrm{C}$ for 4 hours. The obtained pieces were fired in GRHK kiln for 10 hours, under oxidizing conditions at $1235{ }^{\circ} \mathrm{C}$ temperature.

\section{Whiteness and dimensional measurement}

The whiteness level of the obtained color slabs were measured by Konica Minolta Chroma meter. First, the Chroma meter was calibrated by 
using the calibration plate, and then it was kept on the surface of the color slab to obtain weight, diameter, height of the glazed. Novel Bone china items (creamers) were measured to verify whether those products meet the standard parameters of the Bone china bodies manufactured at the commercial level.

\section{Dye absorption and Strength determination}

The hard biscuit item was cut into two halves and one of them was dipped in the cobalt dye for 45 minutes. Then, the piece was washed with tap water and observed the dye absorption.

The strength of the Bone china products were measured by means of the bending rods. Two samples from the standard slip and the test slip of BC_1 were obtained. The two slips were poured into the two molds separately. The mold parts were detached after 1 hour and the obtained rods were kept on a flat surface and oven dried for 2 hours at $100{ }^{\circ} \mathrm{C}$. Oven dried samples were kept on the surface of the color slab to obtain readings for white, green and yellow hues.

Finally, oven dried rods were placed on the stand and fired in the kiln at $1225-1235{ }^{\circ} \mathrm{C}$ for 10 hours. The bending angles of the bending rods were measured using the protractor. The deviation from $60^{\circ}$ angle was used to determine the bending ability of the rods.

\section{RESULTS AND DISCUSSION}

Characterization of the commercially available Bone ash and the synthesized product

\section{FTIR Analysis}

Fig. 1(a) indicates the FTIR spectrum of the commercially available Bone ash which was taken as the reference and Fig. 1(b) denotes the spectrum of the synthesized product.

— Referenced Bone ash

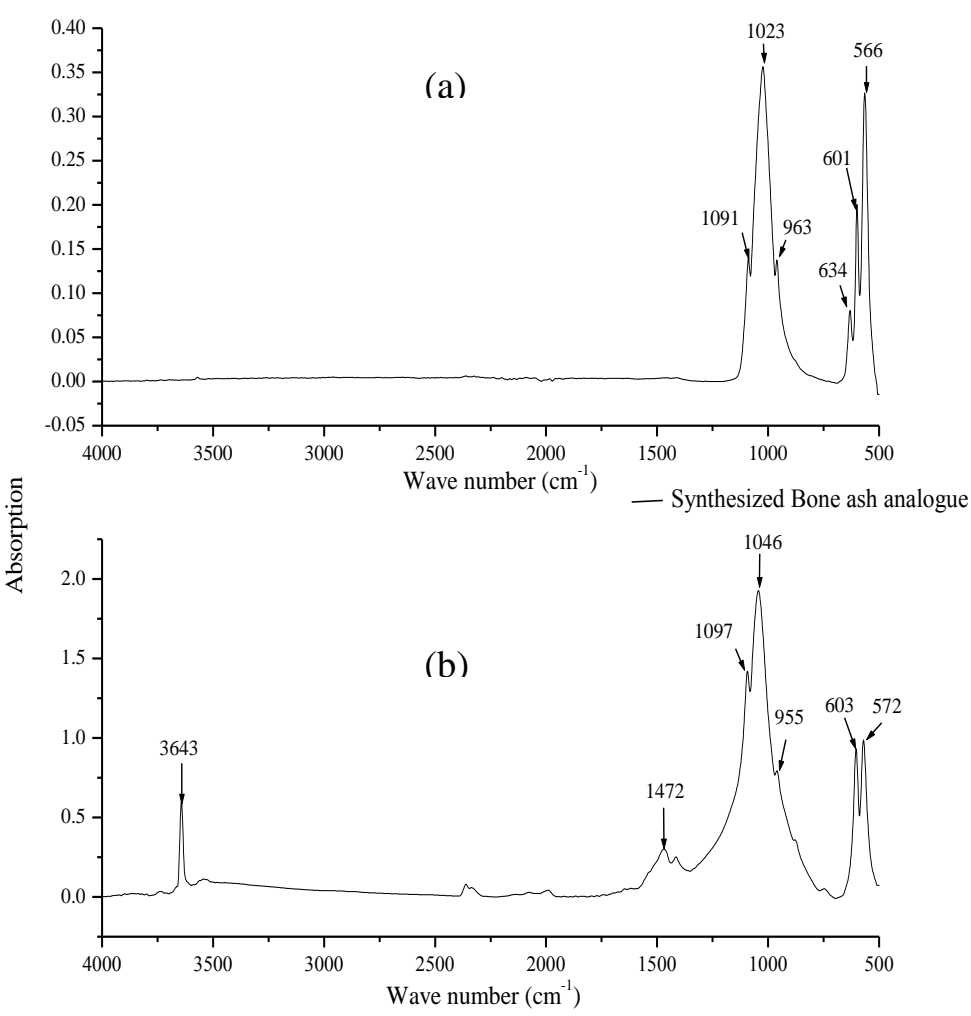

Fig. 1. The FTIR spectrum of (a) Referenced Bone ash (b) Synthesized Bone ash Analogue (BA_900) 
Main constituent of Bone ash is hydroxyapatite and it has chemical formula of $\left[\mathrm{Ca}_{5}(\mathrm{PO} 4)_{3} \mathrm{OH}\right.$ or $\left.\mathrm{Ca}_{10}(\mathrm{PO} 4)_{6} \mathrm{OH}_{2}\right]$. Therefore, analysis of vibrational modes of $\mathrm{PO}_{4}{ }^{3-}$ and $\mathrm{OH}^{-}$functional groups is a good indicator to compare the structural similarities of synthetic and commercial Bone ashes.

The highest absorbance peaks found at $1023 \mathrm{~cm}^{-}$ ${ }^{1}$ and $566 \mathrm{~cm}^{-1}$ in the referenced Bone ash are considered as the characteristic peaks of Bone ash and they have been originated due to the vibrations of $\mathrm{PO}_{4}{ }^{3-}$ functional groups. Further, the vibrations of $\mathrm{PO}_{4}{ }^{3-}$ functional groups have indicated peaks at the wave numbers of 601,963 and $1091 \mathrm{~cm}^{-1}$. Also, the peak at $634 \mathrm{~cm}^{-1}$ is correspond to the $\mathrm{OH}^{-}$functional groups present in the referenced Bone ash.

In accordance, the peaks appeared centering the wave numbers of 1097, 1046, 955, 603 and 572 $\mathrm{cm}^{-1}$ in BA_900, are correspond to the $\mathrm{PO}_{4}{ }^{3-}$ functional groups. The moderately intense peak in BA_900, at the wave number of $3643 \mathrm{~cm}^{-1}$ has been assigned for the $\mathrm{OH}^{-}$functional groups

The narrow high intense peaks of the referenced in the product. According to the available literature, the most prominent peak in BA_900, occurring at the wave number of $1046 \mathrm{~cm}^{-1}$ can be assigned for the asymmetric stretching modes of $\mathrm{P}-\mathrm{O}$ bonds of $\mathrm{PO}_{4}{ }^{3-}$ groups in the synthesized product. Whereas, the broad low intensity peak that lies at a wave number of $1472 \mathrm{~cm}^{-1}$ can be allocated for the $\mathrm{CO}_{3}{ }^{2-}$ impurities. Even though the spectrum 1(b) indicates residual peaks, it could be stated that the presence of impurities is at a lower level as the peaks have low intensities (Mangalaraj et al., 2015; Boujaady et al., 2016).

\section{XRD Analysis}

$\mathrm{X}$-ray diffraction analysis is a powerful technique and can be used to identify the phase analysis and obtain crystallographic data. Fig. 2 shows the XRD pattern of the referenced Bone ash sample and the synthesized product. Here, the XRD patterns have been intentionally restricted to a range where prominent peaks are assumed to occur.

Bone ash can be attributed to the higher

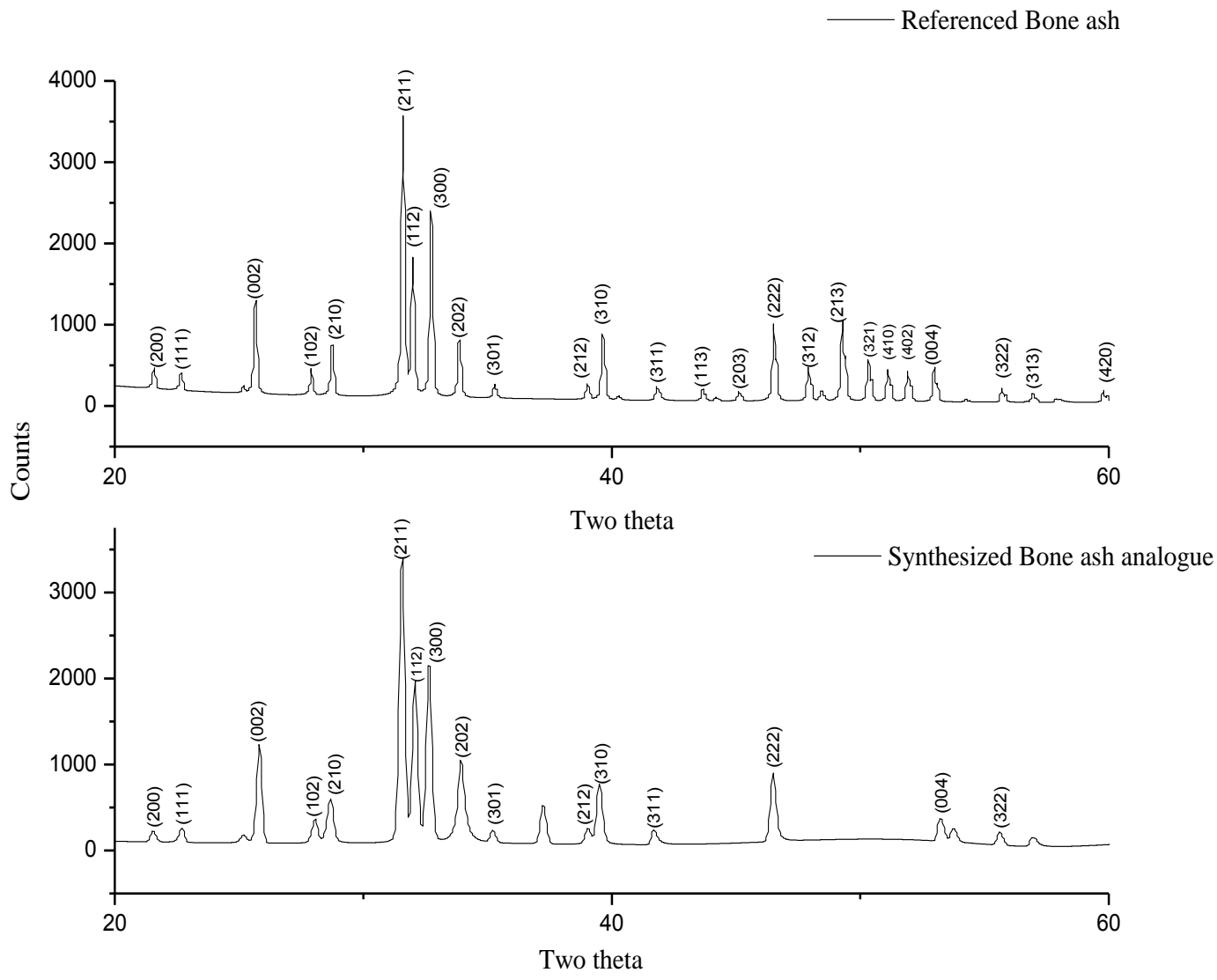

Fig. 2. The XRD spectra of the referenced Bone ash and the synthesized product 
crystallinity and the large crystallite size of the sample. The prominent peaks in the XRD pattern of the referenced Bone ash have been identified as indicated in the spectrum, following the previously recorded data. Also, the literature mentions that the inherent crystallinity of Bone ash is the hexagonal crystal structure.

By referring to the XRD spectrum of the referenced Bone ash, the XRD peaks of the synthesized product have also been recognized and emphasized in the spectrum itself. Therefore, the synthesized product also possesses the characteristic hexagonal structure. Additionally, the moderately broadened diffraction peaks are attributed to the smaller crystallite size and the high crystallinity of the synthesized product. According to the previous research, the high intensity diffraction peaks of the spectrum of the synthesized product manifest that the particles are less coated with impurities ( Pramanik et al., 2007; Okada and Matsumoto, 2015).

\section{XRF Analysis}

The XRF analysis can be used to obtain the elemental compositions of most of inorganic materials. Table 2 shows the major elements found for referenced Bone ash and the synthesized sample. Detailed XRF data is given in the Appendix 1 and Appendix 2.

The XRF data was aided to clarify whether the synthesized product contains similar elemental composition to commercial Bone ash.

According to the data, the referenced Bone ash consist of $\mathrm{CaO}, \mathrm{P}_{2} \mathrm{O}_{5}, \mathrm{SiO}_{2}, \mathrm{Na}_{2} \mathrm{O}, \mathrm{MgO}, \mathrm{Zr}$, $\mathrm{Al}_{2} \mathrm{O}_{3}, \mathrm{Ba}, \quad \mathrm{K}_{2} \mathrm{O}$ and $\mathrm{SO}_{3}$ as the major components. $\mathrm{Zn}, \mathrm{Sm}, \mathrm{Eu}, \mathrm{Sr}, \mathrm{Fe}_{2} \mathrm{O}_{3}, \mathrm{Cl}, \mathrm{V}, \mathrm{Sn}$, $\mathrm{Ta}, \mathrm{Re}, \mathrm{Au}, \mathrm{Fr}, \mathrm{Te}, \mathrm{Cu}, \mathrm{Rb}, \mathrm{Br}$ are included as the minor constituents (Appendix 1).

Among these constituents, $\mathrm{CaO}$ which forms the crystalline phase of Bone china accounts for $73.1 \%$ of the composition. The glass former in Bone china; $\mathrm{P}_{2} \mathrm{O}_{5}$ is responsible for $22.9 \%$ percent of the compound. Similarly, the synthesized product also carries more than $70 \%$ of $\mathrm{CaO}$ and nearly $18 \%$ of $\mathrm{P}_{2} \mathrm{O}_{5}$.

The referenced product bears $0.29 \%$ of $\mathrm{Al}_{2} \mathrm{O}_{3}$ while the synthesized product has $0.4 \%$ of
$\mathrm{Al}_{2} \mathrm{O}_{3}$, which contributes for the strength of the Bone china (Zakaria and Haron, 2013).

Table 2. The essential elemental compositions of the referenced Bone ash and the synthesized product.

\begin{tabular}{ccc}
\hline Component & $\begin{array}{c}\text { Component } \\
\text { percentage in } \\
\text { Referenced } \\
\text { Bone ash }\end{array}$ & $\begin{array}{c}\text { Component } \\
\text { percentage } \\
\text { in BA_900 }\end{array}$ \\
\hline $\mathrm{CaO}$ & 73.1000 & 78.5000 \\
$\mathrm{P}_{2} \mathrm{O}_{5}$ & 22.9000 & 17.2000 \\
$\mathrm{SiO}_{2}$ & 1.5000 & 1.2100 \\
$\mathrm{Na}_{2} \mathrm{O}$ & 0.7960 & 0.6630 \\
$\mathrm{Al}_{2} \mathrm{O}_{3}$ & 0.2910 & 0.4040 \\
$\mathrm{Cl}$ & 0.0128 & 0.1230 \\
$\mathrm{Fe}_{2} \mathrm{O}_{3}$ & 0.0140 & 0.0632 \\
$\mathrm{~F}$ & 0.0000 & 0.000 \\
\hline
\end{tabular}

The results indicate that the presence of $\mathrm{Cl}, \mathrm{F}$ and $\mathrm{Fe}_{2} \mathrm{O}_{3}$ in the synthesized product is approximately similar to the referenced Bone ash. Their presence is very low compared with the other elements.

\section{Characterization of Ceramic Ware}

In Bone china preparation the particle size of the initial slip should be in the range of 78-82 $\mu \mathrm{m}$ and the final slip must have a particle size range of $80-84 \mu \mathrm{m}$. The required viscosity range must be $800-1000 \mathrm{cP}$ while the moisture level should be $29.5-30 \%$. The successive ball milling was aided in obtaining the required particle size and Aqualic was used for viscosity adjustments. Because, the addition of water could negatively impacted on the shrinkage of the fired porcelain body.

The tested Bone china ware BC_6, BC_5, BC_4 were unable to be casted by drain casting method. The slip separation was problematic as the clay mixture absorbed the added water. Furthermore, particle size analysis was unable to process as the solid portion was settled at the bottom of the measuring cylinder. BC_ 3 and BC_2 were cracked during the firing process. 
Air bubbles were appeared on the green ware and they would have burst during the firing process. BC_1 test ware was casted, fired and glazed successfully.

The parameters of the standard Bone china ware and the test ware BC_1 are given in Table 3 .

Table 3. The parameters of the Standard Bone china and the Test Bone china

\begin{tabular}{lcccc}
\hline Item & $\begin{array}{c}\text { Height } \\
(\mathbf{c m})\end{array}$ & $\begin{array}{c}\text { Diameter } \\
(\mathbf{c m})\end{array}$ & $\begin{array}{c}\text { Weig } \\
\mathbf{h t}(\mathbf{g})\end{array}$ & $\begin{array}{c}\text { Bending } \\
\text { angle }\left(^{\circ}\right)\end{array}$ \\
\hline $\begin{array}{l}\text { Standard } \\
\begin{array}{l}\text { Bone } \\
\text { china }\end{array}\end{array}$ & 60.8 & 47.8 & 79.8 & 24 \\
BC_1 & 59.2 & 46.9 & 82.5 & 18 \\
\hline
\end{tabular}

The test Bone china ware met the standard dimensions. Some alterations may occur according to the firing conditions, conditions of the molds and raw materials. However, small deviations will not affect for the final product.

When the bending angles are considered, higher bending angles were related to the lower strength and lower bending angles were related to the higher strengths. With regard to the above results, the rods made using the test mixture, have bent with an angle of $18^{\circ}$ and the rods made using the standard mixture have bent with $24^{\circ}$ angle. This fact implies that the test clay mixture has comparatively a higher strength than the standard clay mixture. With reference to the previously obtained XRF data (Table 2, Appendix 1, Appendix 2), it was proved that the synthetic Bone ash has a higher level of $\mathrm{CaO}$ than the referenced Bone ash. In the firing process the synthetic Bone ash has produced a stronger crystalline phase in the rods permitting a less bending ability. Contrastingly, the lower
$\mathrm{CaO}$ content in the referenced Bone ash has produced a weaker crystalline phase allowing a higher bending ability.

The hue values obtained for the prepared color slabs are indicated in Table 4.

" $L$ " value stands for the white hue of the body. " $a$ " value stands for the greenish hue and " $b$ " " value stands for the yellowish hue of the body.

Table 4. Hue values of the color slabs

\begin{tabular}{llll}
\hline Hue & $\mathbf{L}$ & $\mathbf{a}^{-}$ & $\mathbf{b}^{+}$ \\
\hline Standard & 94.30 & 0.51 & 2.29 \\
BC_1 & 90.18 & 0.73 & 4.93 \\
\hline
\end{tabular}

Usually, the Chroma meter is designed to measure the hues of flat ware items. When the item is a hollow ware, the whiteness of the item is measured by preparing a color slab using the slip that is used to cast the specific item. The test Bone china has slightly a lower whiteness level than the standard Bone china. But that whiteness level lies between the commercially accepted, standard whiteness values. Undesirable black spots, bubbles, warps, distortions and colorations did not occur in the test ceramic ware. The novel Bone china items exhibit a significant translucency compared to the standard Bone china product. The items emit a chime sound which is considered as an attractive feature of Bone china.

If dye absorption of the hard biscuit is outstanding, the item has a higher percentage of pore spaces. So, the item would be less strong and glazing is improbable. Since dye absorption was not appear, the produced items have standard strength and standard pore spaces. As the hard biscuit has negligible dye absorption, a glaze could be applied easily.

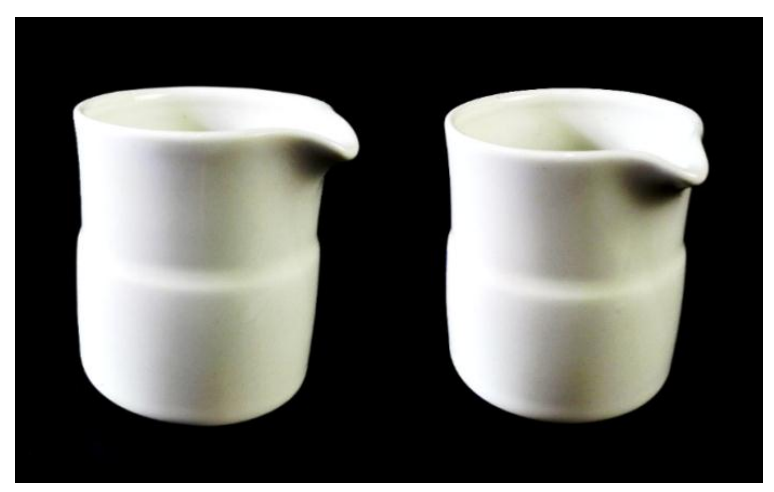

(a)

(b

Fig. 3. The appearance of the (a) Standard Bone china (b) Test Bone china 


\section{CONCLUSION}

In present work, a novel bone china recipe was developed using a synthesized Bone ash analogue from Eppawala apatite with calcium hydroxide. We found that the synthesized material has characteristics features of hydroxyapatite similar to commercial Bone ash. FTIR results clearly indicated that the presence of main functional groups of $\mathrm{PO}_{4}{ }^{3-}$ and $\mathrm{OH}^{-}$in both synthesized and referenced Bone ashes. The high crystalline nature with small crystallite size was observed for synthesized Bone ash from XRD data with lesser amounts of impurities. The synthesized Bone ash also retains the inherent hexagonal crystal structure similar to the referenced Bone ash. The high intensity XRD peaks suggested that the particles are less coated with foreign materials. Further, $\mathrm{CaO}$ and $\mathrm{P}_{2} \mathrm{O}_{5}$ were found as the major constituents whereas fluorine, chlorine and iron were identified in very minor levels. Thus, the synthesized Bone ash analogue could meet the industrial parameters.

Even though the synthesized Bone ash has similar functional groups to the referenced sample, same crystallographic structure and approximate elemental composition, its practical applications show some deviations.

The test Bone china ware BC_6, BC_5, BC_4 were unable to be casted as the slip formation was impracticable. The mixture absorbs water in the mixture. The addition of excess aqualic permitted the slip formation. But aqualic causes color alterations in the final Bone china product.

The test Bone china BC_3 and BC_2 were unable to be fired. When the green ware was fired, bubbles were burst and caused cracks in the Bone china body.

The test ware BC_1 was successfully casted, dried, fired and glazed to obtain the Bone china product. The product had the desired whiteness level, weight, translucent property and chime attribute. It was stronger and undesirable bubbles, colorations, warps, distortions and black dots were not visible. But, further developments in the recipe would produce more economically and practically feasible products with improved physical and chemical properties.
So, it can be stated that the synthesized Bone ash product is practically viable to be used as a partial substitute for the commercially available Bone ash. Additionally, the product would act as a complete substitute in other ceramic manufacturing methods.

\section{ACKNOWLEDGEMENT}

The technical support given by the staff of Noritake Lanka porcelain (pvt) Ltd is highly appreciated. The academic and Non-academic staff of Uva Wellassa University have done tremendous work in this study.

Appendixes: www.gsslweb.org

\section{REFERENCES}

Boujaady, H. El, Mourabet, M., Rhilassi, A. E. L., Bennani- Ziatni, M., Hamri, R. El and Taitai, A. (2016). ( CDHAp ): Kinetic and thermodynamic studies Adsorption of a textile dye on synthesized calcium deficient hydroxyapatite ( CDHAp ): Kinetic and thermodynamic studies. Journal of Material Environmental Sciences, 7(October), 4049-4063.

Braganca, S. R, and Bergmann, C. P. (2008). A comparative study between bone China and hard porcelain. Industrial Ceramics, 28(December 2008).

Hills, B., Porta, P. E. P. and Dwight, H. (1998). Synthetic Bone ash.

Irvine, G. D. (1980). Synthetic Boe Ash (U.S. Patent No.4274879). England.

Manoj, M., Mangalaraj, D., Ponpandian, N. and Viswanathan, C. (2015). Core-shell hydroxyapatite/Mg nanostructures: surfactant free facile synthesis, characterization and their in vitro cell viability studies against leukaemia cancer cells (K562). Royal Society of Chemistry Advances, 5(May), 48705-48711.

Mostari, M. S., Zaman, T. and Rahman, M. S. (2017). Synthesis and Characterization of Bone \& Teeth Ash and Analysis of Their Influence on the Properties of Bone China. International Journal of Materials Science and Applications, 6(4), 171-177.

Nijhawan, K. K. and Taylor, D. (1975). Bone China (U.S.Patent No.3,893,841). England.

Okada, M. and Matsumoto, T. (2015). Synthesis and modification of apatite nanoparticles 
for use in dental and medical applications. Japanese Dental Science Review, 51(4), 85-95.

Pramanik, S., Agarwal, Avinash, K., Rai, K. N. and Garg, A. (2007). Development of high strength hydroxyapatite by solid-statesintering process. Ceramics Internationsl, 33, 419-426.

Singer, F. (1963). Industrial-ceramics (1st ed.). Springer Netherlands.

Smith, R. W. (2013). Porcelain and Bone China. www.rwsmithco.com/catalog/TriMarkRW-Smith-Porcelain-Bone-China-Guide.

Subasinghe, N. D. (1991). Mineralogical , chemical and solubility variations in the Eppawala phosphate deposit of Sri Lanka
- a case for selective mining for fertilizers Mineralogical, chemical and solubility variations in the Eppawala phosphate deposit of Sri Lanka - a case for. Nutrient Cycling in Agroecosystems, 28(May 1991), 233-238.

Zakaria, Z. and Haron, H. (2013). Characterisation of Local Bone Ash for Bone China Production. Teknologi (Sceinces and Engineering), (December 2013), 25-34. 


\section{Appendix 1}

The XRF analysis of the referenced Bone ash sample

\begin{tabular}{|c|c|c|c|c|c|c|}
\hline No & Component & Result & Unit & $\begin{array}{l}\text { Statistical } \\
\text { error }\end{array}$ & $\begin{array}{l}\text { Detection } \\
\quad \text { limit }\end{array}$ & $\begin{array}{l}\text { Quantition } \\
\text { limit }\end{array}$ \\
\hline 1 & $\mathrm{CaO}$ & 73.1 & mass $\%$ & 0.0687 & 0.0031 & 0.0092 \\
\hline 2 & $\mathrm{P}_{2} \mathrm{O}_{5}$ & 22.9 & mass $\%$ & 0.019 & 0.0246 & 0.0738 \\
\hline 3 & $\mathrm{SiO}_{2}$ & 1.35 & mass $\%$ & 0.0077 & 0.0152 & 0.0457 \\
\hline 4 & $\mathrm{Na}_{2} \mathrm{O}$ & 0.796 & mass $\%$ & 0.0822 & 0.226 & 0.678 \\
\hline 5 & $\mathrm{MgO}$ & 0.564 & mass $\%$ & 0.0124 & 0.0251 & 0.0753 \\
\hline 6 & $\mathrm{Zt}$ & 0.409 & mass $\%$ & 0.0026 & 0 & 0.0025 \\
\hline 7 & $\mathrm{Al}_{2} \mathrm{O}_{3}$ & 0.291 & mass $\%$ & 0.0042 & 0.0073 & 0.0219 \\
\hline 8 & $\mathrm{Ba}$ & 0.176 & mass \% & 0.0022 & 0.0019 & 0.0057 \\
\hline 9 & $\mathrm{~K}_{2} \mathrm{O}$ & 0.157 & mass $\%$ & 0.0024 & 0.0015 & 0.0046 \\
\hline 10 & $\mathrm{SO}_{3}$ & 0.131 & mass $\%$ & 0.0011 & 0.0016 & 0.0047 \\
\hline 11 & $\mathrm{Zn}$ & 0.0293 & mass $\%$ & 0.0004 & 0.0003 & 0.001 \\
\hline 12 & $\mathrm{Sm}$ & 0.028 & mass \% & 0.0017 & 0.002 & 0.006 \\
\hline 13 & $\mathrm{Eu}$ & 0.0236 & mass $\%$ & 0.0015 & 0.0012 & 0.0036 \\
\hline 14 & $\mathrm{Sr}$ & 0.0172 & mass \% & 0.0002 & 0.0003 & 0.0009 \\
\hline 15 & $\mathrm{Fe}_{2} \mathrm{O}_{3}$ & 0.014 & mass $\%$ & 0.0009 & 0.002 & 0.0059 \\
\hline 16 & $\mathrm{Cl}$ & 0.0128 & mass\% & 0.0002 & 0.0002 & 0.0013 \\
\hline 17 & $\mathrm{~V}$ & 0.0025 & mass $\%$ & 0.0008 & 0.002 & 0.0071 \\
\hline 18 & $\mathrm{Sn}$ & ND & mass\% & 0.0002 & 0.0004 & 0.002 \\
\hline 19 & Dy & 0.0016 & mass $\%$ & 0.0009 & 0.0024 & 0.0016 \\
\hline 20 & $\mathrm{Ta}$ & 0.0013 & mass $\%$ & 0.0003 & 0.0008 & 0.0012 \\
\hline 21 & $\mathrm{Re}$ & 0.0012 & mass $\%$ & 0.0002 & 0.0005 & 0.0006 \\
\hline 22 & $\mathrm{Au}$ & 0.001 & mass $\%$ & 0.0002 & 0.0004 & 0.002 \\
\hline 23 & $\mathrm{Fr}$ & 0.001 & mass $\%$ & 0.0001 & 0.0002 & 0.0011 \\
\hline 24 & $\mathrm{Te}$ & 0.001 & mass $\%$ & 0.0002 & 0 & 0.0002 \\
\hline 25 & $\mathrm{Cu}$ & 0.0009 & mass $\%$ & 0.0001 & 0.0004 & 0.02007 \\
\hline 26 & $\mathrm{Rb}$ & 0.0007 & mass $\%$ & $<0.0001$ & 0.0001 & 0.135 \\
\hline 27 & $\mathrm{TIO}_{2}$ & ND & mass \% & 0.0023 & 0.0069 & 0.0003 \\
\hline 28 & $\mathrm{Sc}$ & $\mathrm{ND}$ & mass $\%$ & 0.015 & 0.045 & \\
\hline 29 & $\mathrm{Br}$ & 0.0002 & mass\% & $<0.0001$ & 0.0001 & \\
\hline 30 & $\mathrm{Cr}$ & $\mathrm{ND}$ & mass $\%$ & & & \\
\hline 31 & $\mathrm{Co}$ & ND & mass \% & & & \\
\hline 32 & $\mathrm{Ni}$ & ND & mass $\%$ & & & \\
\hline 33 & $\mathrm{Ga}$ & ND & mass $\%$ & & & \\
\hline 34 & As & ND & mass $\%$ & & & \\
\hline 35 & $\mathrm{Y}$ & $\mathrm{ND}$ & mass \% & & & \\
\hline 36 & $\mathrm{Nb}$ & ND & mass $\%$ & & & \\
\hline 37 & $\mathrm{Ag}$ & $\mathrm{ND}$ & mass \% & & & \\
\hline 38 & $\mathrm{Cd}$ & ND & mass $\%$ & & & \\
\hline 39 & $\mathrm{La}$ & ND & mass \% & & & \\
\hline
\end{tabular}




\begin{tabular}{|c|c|c|c|c|c|c|}
\hline 40 & $\mathrm{Ce}$ & ND & mass $\%$ & & & \\
\hline 41 & $\mathrm{Hf}$ & ND & mass $\%$ & & & \\
\hline 42 & $\mathrm{~W}$ & ND & mass $\%$ & & & \\
\hline 43 & $\mathrm{Pt}$ & ND & mass $\%$ & & & \\
\hline 44 & $\mathrm{Hg}$ & ND & mass\% & & & \\
\hline 45 & $\mathrm{~Pb}$ & $\mathrm{ND}$ & mass \% & & & \\
\hline 46 & $\mathrm{Bi}$ & ND & mass\% & & & \\
\hline 47 & Th & ND & mass $\%$ & & & \\
\hline 48 & $\mathrm{U}$ & ND & mass $\%$ & & & \\
\hline 49 & $\mathrm{MnO}$ & $\mathrm{ND}$ & mass \% & & & \\
\hline 50 & $\mathrm{~F}$ & 0 & mass $\%$ & & & \\
\hline 51 & Mo & $\mathrm{ND}$ & mass \% & & & \\
\hline 52 & $\mathrm{Ru}$ & ND & mass\% & & & \\
\hline 53 & $\mathrm{Rh}$ & ND & mass \% & & & \\
\hline 54 & $\mathrm{Pd}$ & ND & mass\% & & & \\
\hline 55 & $\mathrm{Tc}$ & ND & mass\% & & & \\
\hline 56 & In & ND & mass \% & & & \\
\hline 57 & $\mathrm{Sb}$ & ND & mass\% & & & \\
\hline 58 & $\mathrm{Se}$ & ND & mass $\%$ & & & \\
\hline 59 & $\operatorname{Pr}$ & ND & mass\% & & & \\
\hline 60 & $\mathrm{Nd}$ & ND & mass\% & & & \\
\hline 61 & $\mathrm{Pm}$ & ND & mass\% & & & \\
\hline 62 & $\mathrm{Gd}$ & ND & mass\% & & & \\
\hline 63 & $\mathrm{~Tb}$ & ND & mass\% & & & \\
\hline 64 & Ho & ND & mass\% & & & \\
\hline 65 & $\mathrm{Er}$ & ND & mass\% & & & \\
\hline 66 & $\mathrm{Tm}$ & ND & mass $\%$ & & & \\
\hline 67 & $\mathrm{Tl}$ & ND & mass\% & & & \\
\hline 68 & Os & ND & mass $\%$ & & & \\
\hline 69 & $\mathrm{Ir}$ & ND & mass $\%$ & & & \\
\hline 70 & $\mathrm{Cs}$ & ND & mass\% & & & \\
\hline 71 & $\mathrm{Ra}$ & ND & mass\% & & & \\
\hline 72 & Po & ND & mass $\%$ & & & \\
\hline 73 & $\mathrm{Ge}$ & ND & mass \% & & & \\
\hline 74 & I & ND & mass $\%$ & & & \\
\hline
\end{tabular}




\section{Appendix 2}

The XRF analysis of the synthesized Bone ash analogue

\begin{tabular}{|c|c|c|c|c|c|c|}
\hline No & Component & Result & Unit & $\begin{array}{c}\text { Statistical } \\
\text { error }\end{array}$ & $\begin{array}{l}\text { Detection } \\
\text { limit }\end{array}$ & $\begin{array}{c}\text { Quantition } \\
\text { limit }\end{array}$ \\
\hline 1 & $\mathrm{CaO}$ & 78.5 & mass $\%$ & 0.146 & 0.0032 & 0.0095 \\
\hline 2 & $\mathrm{P}_{2} \mathrm{O}_{5}$ & 17.2 & mass $\%$ & 0.0159 & 0.0214 & 0.0642 \\
\hline 3 & $\mathrm{Na}_{2} \mathrm{O}$ & 1.21 & mass $\%$ & 0.0828 & 0.216 & 0.647 \\
\hline 4 & $\mathrm{Cl}$ & 0.663 & mass $\%$ & 0.001 & 0.0012 & 0.0035 \\
\hline 5 & $\mathrm{Zr}$ & 0.444 & mass $\%$ & 0.0024 & 0.001 & 0.003 \\
\hline 6 & $\mathrm{MgO}$ & 0.417 & mass\% & 0.011 & 0.0229 & 0.0686 \\
\hline 7 & $\mathrm{SiO}_{2}$ & 0.404 & mass $\%$ & 0.004 & 0.0068 & 0.0203 \\
\hline 8 & $\mathrm{Sr}$ & 0.328 & mass $\%$ & 0.0008 & 0.0013 & 0.004 \\
\hline 9 & $\mathrm{SO}_{3}$ & 0.27 & mass \% & 0.0017 & 0.003 & 0.009 \\
\hline 10 & $\mathrm{Al}_{2} \mathrm{O}_{3}$ & 0.123 & mass $\%$ & 0.0032 & 0.007 & 0.0209 \\
\hline 11 & $\mathrm{Ce}$ & 0.101 & mass $\%$ & 0.0023 & 0.004 & 0.0119 \\
\hline 12 & $\mathrm{Eu}$ & 0.00975 & mass\% & 0.003 & 0.001 & 0.0029 \\
\hline 13 & $\mathrm{Sm}$ & 0.0662 & mass $\%$ & 0.0029 & 0.0026 & 0.0079 \\
\hline 14 & $\mathrm{Fe}_{2} \mathrm{O}_{3}$ & 0.0632 & mass\% & 0.0019 & 0.0039 & 0.0116 \\
\hline 15 & $\mathrm{La}$ & 0.0452 & mass $\%$ & 0.0016 & 0.0031 & 0.0093 \\
\hline 16 & $\mathrm{~K}_{2} \mathrm{O}$ & 0.0221 & mass $\%$ & 0.0019 & 0.005 & 0.0149 \\
\hline 17 & $\mathrm{Gd}$ & 0.016 & mass $\%$ & 0.0017 & 0.0037 & 0.0112 \\
\hline 18 & $\mathrm{Y}$ & 0.0083 & mass\% & 0.0001 & 0.0002 & 0.0006 \\
\hline 19 & $\mathrm{Cr}$ & 0.0076 & mass $\%$ & 0.0004 & 0.0009 & 0.0028 \\
\hline 20 & Th & 0.0071 & mass\% & 0.0002 & 0.0004 & 0.0011 \\
\hline 21 & $\mathrm{Tm}$ & 0.0061 & mass $\%$ & 0.0008 & 0.0019 & 0.0058 \\
\hline 22 & $\mathrm{Sn}$ & 0.0026 & mass $\%$ & 0.0002 & 0.0004 & 0.0011 \\
\hline 23 & As & 0.0017 & mass\% & 0.0001 & 0.0003 & 0.0008 \\
\hline 24 & $\mathrm{~Pb}$ & 0.001 & mass\% & 0.0001 & 0.0004 & 0.0012 \\
\hline 25 & Os & ND & mass\% & 0.0003 & 0.0007 & 0.0022 \\
\hline 26 & Po & 0.0005 & mass $\%$ & 0.0001 & 0.0003 & 0.0008 \\
\hline 27 & $\mathrm{Cu}$ & ND & mass\% & 0.0002 & 0.0006 & 0.0018 \\
\hline 28 & $\mathrm{Cd}$ & ND & mass\% & 0.0001 & 0.0003 & 0.0009 \\
\hline 29 & $\mathrm{Hg}$ & ND & mass\% & 0.0002 & 0.0005 & 0.0014 \\
\hline 30 & $\mathrm{~V}$ & ND & mass\% & 0.0008 & 0.0023 & 0.007 \\
\hline 31 & $\mathrm{Sc}$ & ND & mass $\%$ & 0.0049 & 0.0148 & 0.0444 \\
\hline 32 & $\mathrm{Pt}$ & ND & mass\% & 0.0002 & 0.0006 & 0.0017 \\
\hline 33 & $\mathrm{Ir}$ & ND & mass\% & 0.0002 & 0.0007 & 0.002 \\
\hline 34 & $\mathrm{~Tb}$ & ND & mass\% & 0.0017 & 0.0051 & 0.0153 \\
\hline 35 & $\mathrm{MnO}$ & ND & mass\% & 0.0016 & 0.0047 & 0.0141 \\
\hline 36 & $\mathrm{Ta}$ & ND & mass\% & 0.0004 & 0.0011 & 0.0033 \\
\hline 37 & $\mathrm{Se}$ & ND & mass\% & 0.0001 & 0.0002 & 0.0005 \\
\hline 38 & Dy & ND & mass $\%$ & 0.0012 & 0.0035 & 0.0106 \\
\hline 39 & In & ND & mass\% & 0.0001 & 0.0004 & 0.0011 \\
\hline 40 & $\mathrm{Co}$ & ND & mass $\%$ & & & \\
\hline
\end{tabular}




\begin{tabular}{|c|c|c|c|c|c|c|}
\hline 41 & $\mathrm{Ni}$ & ND & mass\% & & & \\
\hline 42 & $\mathrm{Zn}$ & ND & mass\% & & & \\
\hline 43 & $\mathrm{Ga}$ & ND & mass\% & & & \\
\hline 44 & $\mathrm{Rb}$ & ND & mass\% & & & \\
\hline 45 & $\mathrm{Nb}$ & ND & mass\% & & & \\
\hline 46 & $\overline{A g}$ & ND & mass\% & & & \\
\hline 47 & $\mathrm{Ba}$ & ND & mass\% & & & \\
\hline 48 & $\mathrm{Hf}$ & ND & mass $\%$ & & & \\
\hline 49 & $\mathrm{~W}$ & ND & mass\% & & & \\
\hline 50 & $\mathrm{Au}$ & 0 & mass\% & & & \\
\hline 51 & $\mathrm{Bi}$ & ND & mass\% & & & \\
\hline 52 & $\mathrm{U}$ & ND & mass\% & & & \\
\hline 53 & $\mathrm{TIO}_{2}$ & ND & mass \% & & & \\
\hline 54 & $\mathrm{~F}$ & 0 & mass \% & & & \\
\hline 55 & Mo & ND & mass\% & & & \\
\hline 56 & $\mathrm{Ru}$ & ND & mass\% & & & \\
\hline 57 & $\mathrm{Rh}$ & ND & mass\% & & & \\
\hline 58 & $\mathrm{Pd}$ & ND & mass\% & & & \\
\hline 59 & $\mathrm{Tc}$ & ND & mass\% & & & \\
\hline 60 & $\mathrm{Sb}$ & ND & mass\% & & & \\
\hline 61 & $\operatorname{Pr}$ & ND & mass\% & & & \\
\hline 62 & $\mathrm{Nd}$ & ND & mass\% & & & \\
\hline 63 & $\mathrm{Pm}$ & ND & mass\% & & & \\
\hline 64 & Ho & ND & mass\% & & & \\
\hline 65 & $\mathrm{Er}$ & ND & mass\% & & & \\
\hline 66 & $\mathrm{Tl}$ & ND & mass\% & & & \\
\hline 67 & $\operatorname{Re}$ & ND & mass\% & & & \\
\hline 68 & Cs & ND & mass \% & & & \\
\hline 69 & $\mathrm{Fr}$ & ND & mass\% & & & \\
\hline 70 & $\mathrm{Ra}$ & ND & mass \% & & & \\
\hline 71 & $\mathrm{Te}$ & ND & mass\% & & & \\
\hline 72 & $\mathrm{Ge}$ & ND & mass\% & & & \\
\hline 73 & $\mathrm{Br}$ & ND & mass\% & & & \\
\hline 74 & I & ND & mass\% & & & \\
\hline
\end{tabular}

